\title{
Complementary studies of mitochondrial DNA of male fertile plants obtained by mutagenic treatment of a cytoplasmic male sterile line of maize
}

\author{
Elisabeth VUILLAUME, Chantal MATHIEU $\left({ }^{*}\right) \&$ Fernand VEDEL $\left({ }^{*}\right)$ \\ I.N.R.A., Station d'Amélioration des Plantes, B.V. 1540, F 21034 Dijon Cedex \\ (*) C.N.R.S., Laboratoire de Photosynthèse, F 91190 Gif-sur-Yvette
}

Cytoplasmic male fertile mutants were obtained after mutagenic treatment of the Texas cytoplasmic male sterile line of maize : F7 T. Analyses of mitochondrial DNA of these mutants showed : 1) all native and digested mtDNA's of these mutants migrated identically with the mtDNA of the line F7 with Normal cytoplasm ; 2) all these mtDNA's were different from the mtDNA of line F71 with Normal cytoplasm. This line was the pollinator of the plants grown from the treated seeds of F7 T. The mutagenic treatment did not induce cytoplasmic variability in A types. Mutants seemed to come from the same reversion from Texas to Normal cytoplasm. The reversion could not be explained by pollen transmission of mitochondria to the zygote.

Additional key words : Zea mays, extra-nuclear heredity, Helminthosporium maydis race $T$.

Etude complémentaire des DNA mitochondriaux des plantes mâle-fertiles obtenues après traitement mutagène d'un maîs mâle-stérile cytoplasmique.

Des mutants mâle-fertiles cytoplasmiques de maîs ont été obtenus par traitement mutagène de la lignée mâlestérile cytoplasmique Texas : F7 T. L'étude des DNA mitochondriaux de ces mutants fait apparaître : 1) que les mtDNA natifs et digérés par les enzymes de restriction de ces mutants sont identiques entre eux et au mtDNA de la lignée F7 sur cytoplasme Normal ; 2) que ces mtDNA diffèrent du mtDNA de la lignée F71 sur cytoplasme Normal. Cette lignée a servi à polliniser les plantes issues des graines traitées de F7 T. Le traitement mutagène n'a pas permis d'induire de variabilité cytoplasmique dans les types $\mathrm{A}$. Les mutants semblent tous correspondre à la même réversion du cytoplasme Texas vers le cytoplasme Normal. Cette réversion ne peut s'expliquer par la transmission au zygote de mitochondries du pollen.

Mots clefs additionnels : Zea mays, hérédité extra-nucléaire, Helminthosporium maydis race $T$.

\section{INTRODUCTION}

Mutants resistant to Helminthosporium maydis race $\mathrm{T}(\mathrm{HmT})$ were obtained by mutagenic treatment of the line F7 with Texas male sterile cytoplasm (F7 T) which is susceptible to HmT. This resistance is maternally inherited and is always associated with reversion to male fertility. These mutants were called $A$ type mutants (CASSINI et al., 1977 ; CORNU et al., 1977 ; CORNU et al., 1981).

Previous studies have shown that it is possible to characterize cytoplasmic male sterilities in maize by differences in their mitochondrial DNA (mtDNA)
(LEVINGS et al., 1979 ; KEMBLE \& BEDBROOK, 1980 ; KEMBle et al., 1980). BeRVILle \& PAILlaRd (1982) observed that mtDNA from A type mutants was identical to that from line F7 with Normal cytoplasm (F7 N) when these mtDNA's were digested by the restriction enzymes Sal $I$ and Hind III. Vuillaume et al. (1984) showed that native mtDNA migration of $\mathrm{A}$ types was characterized by the absence of the $2.35 \mathrm{~kb}$ mtDNA molecule as is usually the case for mtDNA of Texas cytoplasm. Therefore the hypothesis of a simple reversion from the $\mathrm{T}$ cytoplasm to the $\mathrm{N}$ cytoplasm was questionable. However, two cases of $\mathrm{N}$ cytoplasm with a native mtDNA lacking the $2.35 \mathrm{~kb}$ molecule have already been described (KEMBLE et al., 1983; 
NEWTON, 1983). As we do not know whether the native mtDNA of the line $\mathrm{F} 7$ with $\mathrm{N}$ cytoplasm has the $2.35 \mathrm{~kb}$ molecule we must verify it, even if it implies a role of the nuclear genotype in the process of reversion.

One of the hypotheses made in our laboratory to explain reversion to the normal phenotype suggested that mutagenic treatment allows transmission of pollen organelles to the zygote during fertilization. To check this hypothesis mtDNA of the male parent in the first cross after mutagenic treatment must be analysed. The pollinator was line F71 with $\mathrm{N}$ cytoplasm, having the genes $\mathrm{Rf} 1$ and $\mathrm{Rf} 2$ that restored male fertility for $\mathrm{T}$ cytoplasm.

\section{MATERIAL AND METHODS}

\section{A. Material}

The genotypes analysed were lines F7 T, F7 N, A632 N, and F71 $\mathrm{N}$ and the offsprings of the mutant families of A type number 135, 473, 511, 552 and 1754 with the nucleus genotypes A632.

Five day old etiolated shoots were used for biochemical assays.

\section{B. Methods}

Preparation of native mtDNA followed the techniques described by VUILLAUME et al. (1984). Isolation of mitochondria, mtDNA purification, digestion by restriction enzymes and electrophoretic migrations were described by VEDEL et al. (1980).

The restriction enzymes used were $B a m H I, E c o R I$, Sal I, Bgl I, Hind III, Xho I, Kpn I and Hpa II (Boehringer). $0.7 \%$ agarose gels were used to separate the mtDNA fragments for all the enzymes except Hpa $I I$ and Hind $I I I$ which required $1.2 \%$ agarose gels.

\section{RESULTS}

\section{A. Native mtDNA}

The $2.35 \mathrm{~kb}$ molecule was found in lines A632 and F71 with $\mathrm{N}$ cytoplasm but not in lines F7 with $\mathrm{T}$ or $\mathrm{N}$ cytoplasm nor in the A types (fig. 1).

\section{B. Digested mtDNA}

mtDNA's of F7 N, F7 T, F71 and mutants 135, $473,511,552$ and 1754 were digested by Eco $R I$ (fig. 2A), Sal I (fig. 2B), BamH I (fig. 3).

mtDNA's of F7 N, F71, 135, 473, 511 and 1754 were also restricted by Xho I, $\mathrm{kpn} \mathrm{I,BglI}$, Hind III and $H p a I I$ (fig. 4A, B, C, D). The digestion by Hpa II was incomplete, so the results are not shown.

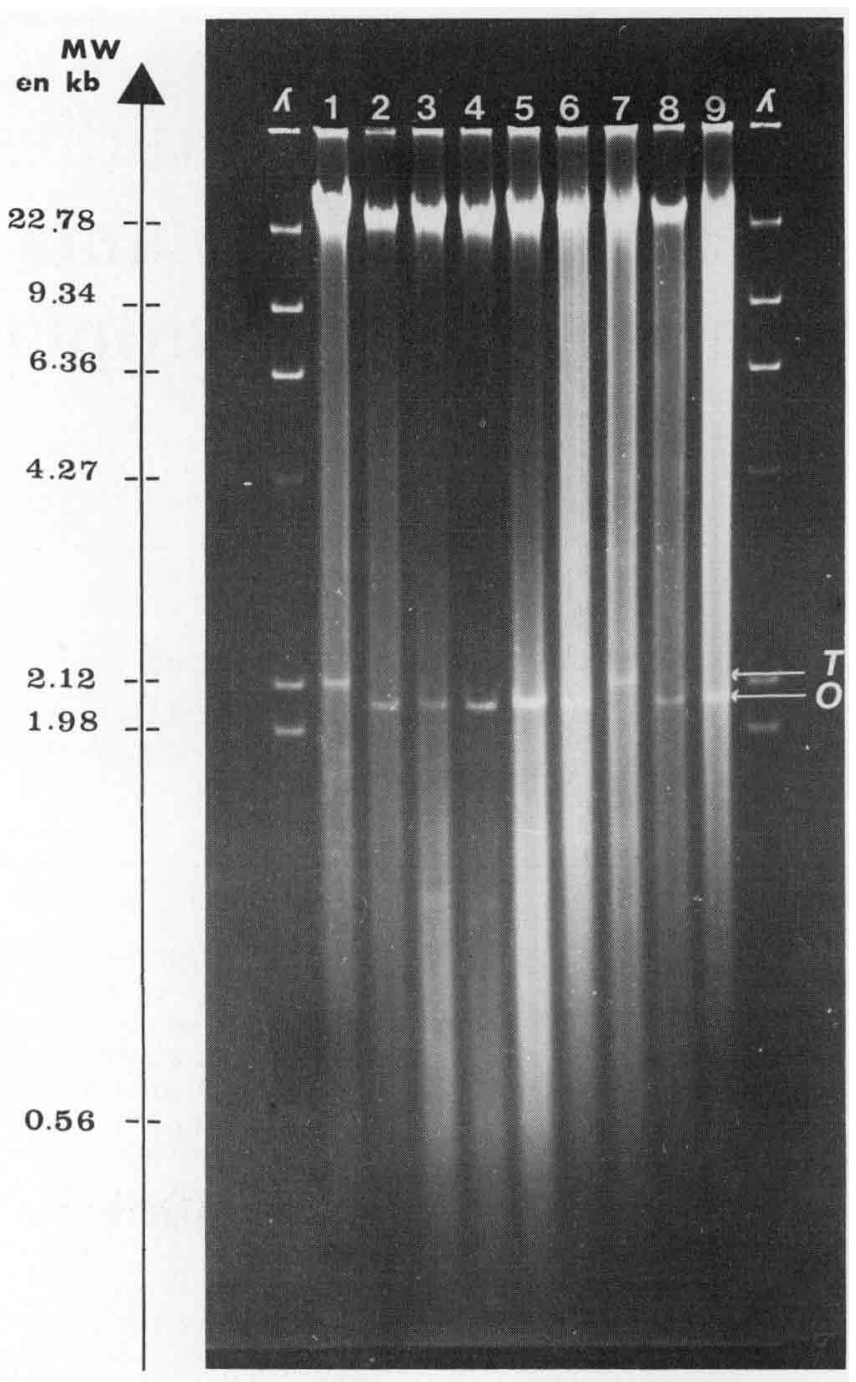

Figure 1

Agarose gel electrophoretic patterns of native mtDNA of maize. Lane 1:A632 N. Lanes 2, 3, 4, 5, 6: the five mutant families 1754, 552, 511, 473, 135. Lane 7:F71. Lane 8:F7 T. Lane 9:F7N. $T$ : the $2.35 \mathrm{~kb} D N A$ characteristic of $N$ maize cytoplasm. $O$ : the open circle from of the common DNA of $1.94 \mathrm{~kb}$. Molecular weight markers are digests of DNA restricted by Eco RI and Hind III (Boehringer, marker III).

Diagrammes électrophorétiques sur gel d'agarose de mtDNA natif de maïs. Puits $1:$ A632 N. Puits 2, 3, 4, 5, 6: les cinq familles de mutants 1754, 552, 511, 473, 135. Puits 7:F71. Puits 8:F7T. Puits $9:$ : 77 N.

$T: D N A$ de $2,35 \mathrm{~kb}$ caractéristique du cytoplasme Normal du maïs. $O$ : forme circulaire ouverte du DNA commun de l,94 kb. Les marqueurs de masses moléculaires sont des fragments de DNA du phage digéré par Eco RI et Hind III (Boehringer, marker III).

In every case digested mtDNA's of A types comigrated with digested mtDNA of F7 N. Migration patterns of A types were always different from both F7 $\mathrm{T}$ and F71 which themselves differed from each other in their migration patterns.

\section{CONCLUSION}

A types appeared as reversion of $\mathrm{T}$ cytoplasm to $\mathrm{N}$ cytoplasm, in the F7 nuclear background which is associated with a particular native mtDNA. However 


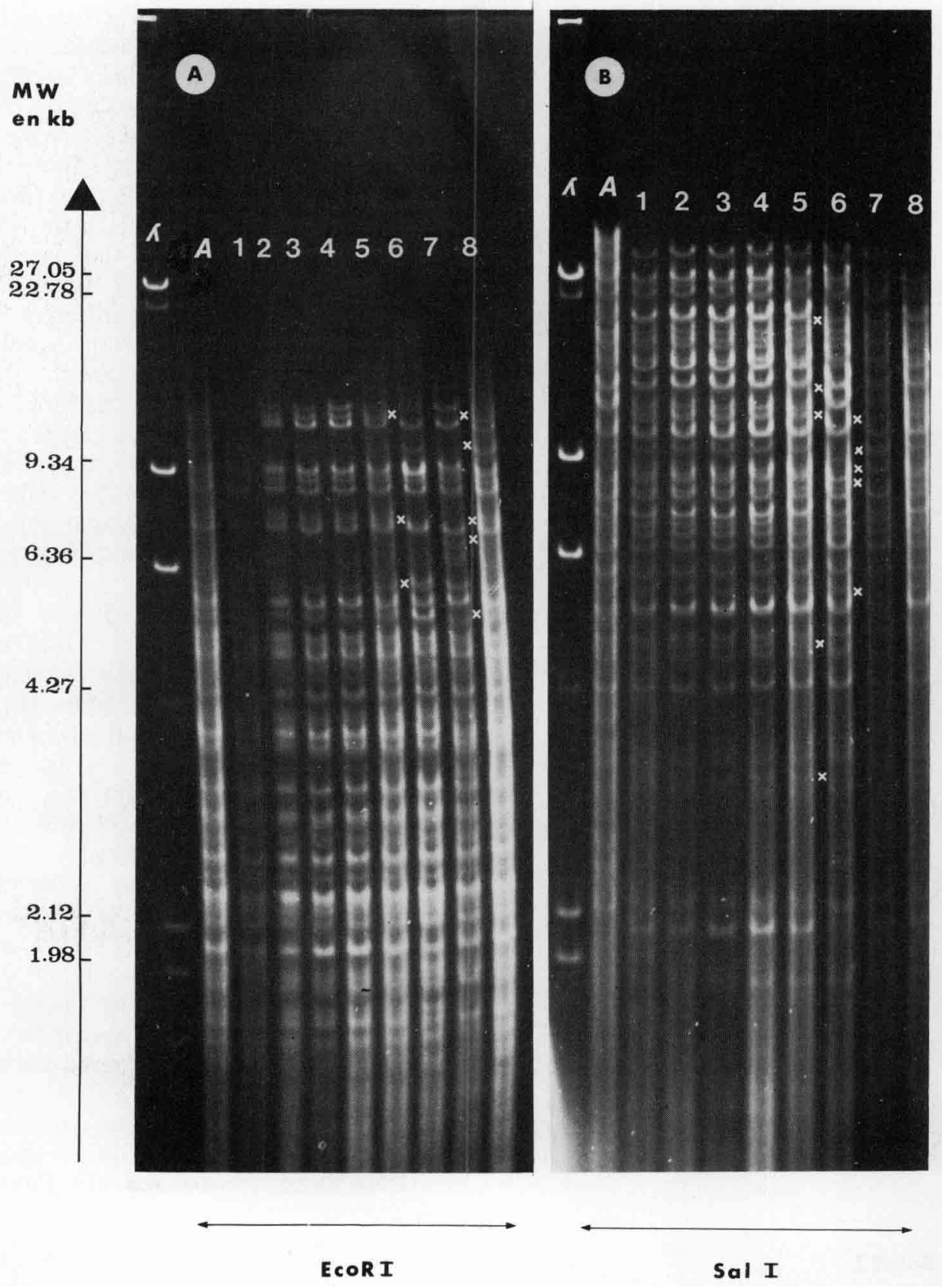

Figure 2A, B

Agarose gel electrophoretic patterns of mtDNA of maize digested by Eco RI (A) and Sal I (B). Lane A : A632 N incompletely digested). Lanes $1,2,3,4,5$ : the five mutant families 1754, 552, 511 , 473, 135. Lane 6:F71. Lane 7:F7 T. Lane 8:F7 N.

Molecular weight markers are digests of DNA restricted by Hind III (Boehringer, marker II).

$\mathrm{x}$ : differences between $F 71$ and $F 7 \mathrm{~N}, 1754,552,511,473,135$ or differences between $F 7 T$ and $F 7 \mathrm{~N}, 1754,552,511,473,135$.
Diagrammes électrophorétiques sur gel d'agarose de mtDNA de maïs digéré par Eco RI (A) et Sal I $(B)$. Puits $A: A 632 N$. Puits 1 , 2, 3, 4, 5 : les cinq familles de mutants 1754, 552, 511, 473, 135. Puits 6:F71. Puits $7: F 7$ T. Puits $8: 17 \mathrm{~N}$.

Les marqueurs de masses moléculaires sont des fragments de DNA du phage digéré par Hind III (Boehringer, marker II). $\mathrm{x}$ : différences entre $F 71$ et $F 7 \mathrm{~N}, 1754,552,511,473,135$ ou, différences entre $F 7 \mathrm{~T}$ et $\mathrm{F7} \mathrm{N}, 1754,552,511,473,135$. this native mtDNA does not seem to play any role in the appearance of $A$ types. If the absence of the $2.35 \mathrm{~kb}$ molecule plays any role in the appearance of A types, we must have had them with the treatment of A188 T, as KEMBLE et al. (1983) have shown that A188 with $\mathrm{N}$ cytoplasm has no $2.35 \mathrm{~kb}$ mtDNA molecule. This was not the case in our study.

Because the native and digested mtDNA of line F71 are different from that of A types, we can exclude the hypothesis of pollen transmission of organelles to the zygote due to mutagenic treatment.
The hypothesis of a stabilized mixture of $\mathrm{T}$ and $\mathrm{N}$ mitochondria in the $T$ cytoplasm, which mutagenic treatment destabilized, is as likely as the hypothesis of a " chromosomic rearrangement" of mtDNA. However we do not presently have the means of distinguishing between these two hypotheses. To clarify these hypotheses, we would like to know the rate of propagation of this mitochondrial genotype in cell lines and how it is stabilized after a few generations of mitosis. First we believe the process takes a long time because we have observed in $\mathrm{A}$ types, segregation of 


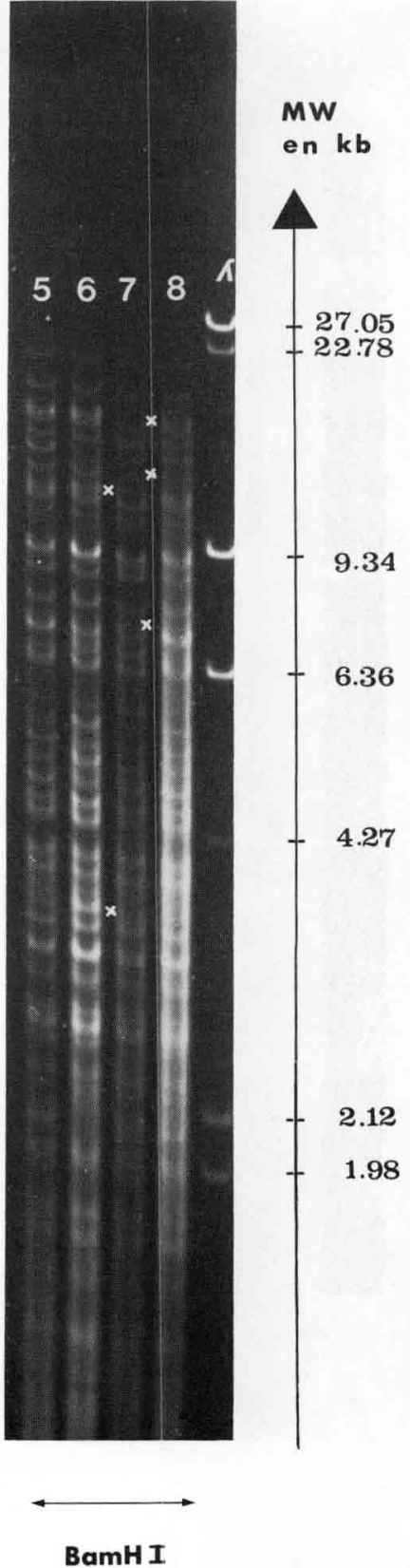

BamH I

Figure 3

Agarose gel electrophoretic patterns of mtDNA of maize digested by BamH I. Lane $5:$ the mutant family 135. Lane $6:$ F7l. Lane 7 : F7 T. Lane $8: F 7 N$.

Molecular weight markers are digests of DNA restricted by Hind III (Boehringer, marker II).

$\mathrm{x}:$ differences observed between $F 71$ and $F 7 N$ and 135 or between F7 $T$ and $F 7 \mathrm{~N}$ and 135.

Diagrammes électrophorétiques sur gel d'agarose du mtDNA de maïs digéré par BamH I. Puits 5: la famille de mutant 135. Puits 6:F71. Puits $7: F 7$ T. Puits $8: F 7 N$.

Les marqueurs de masses moléculaires sont des fragments de DNA du phage digéré par Hind III (Boehringer, marker II).

$\mathrm{x}$ : différences observées entre $F 71, F 7 \mathrm{~N}$ et 135 ou, entre $F 7 \mathrm{~T}, F 7 \mathrm{~N}$ et 135 . susceptibility and resistance for five generations of plants after mutagenic treatment. However, we were unable to follow segregation of sterility and fertility as the first cross by F71 after mutagenic treatment restored male fertility. The M2 was fully fertile and after selfing M2, the M3 theoretically had one fourth male sterile plants. Each male sterile plant was crossed by a maintainer and each male fertile plant was selfed. For A types in the M3 we found that family 1754 had fully male fertile progeny and the others had types of male sterilities which were quite different from Texas male sterility (no tassel, tassel with incomplete flowers or flowers with no anthesis but with fertile pollen). Test crosses showed that these sterilities originated from nuclear factors. So it seems that the behaviour of the two linked characters, male fertility and resistance, is not identical but this may be due to the reliability of the tests for resistance. So the question of the speed of propagation of new mitochondrial genotype remains unsolved.

From in vitro callus cultures of Texas maize, GENGENBACH et al. (1975) and BRETTELl et al. (1980) were able to regenerate plants as resistant to $\mathrm{Hmt}$ and fully male fertile as one A types. If these phenotypes seem similar, the mitochondrial genotypes observed by electrophoretic patterns of digested mtDNA are different. There is variability for mtDNA of plants issued from in vitro culture (GENGENBACH et al., 1981; KEMBLE et al., 1982; WISE et al., 1985). This variability does not seem to be the variability already described for N cytoplasm by LEVINGS \& PRING (1977) and by PRING \& SMITH (1985). Comparison of the mtDNA's of A types and of different kinds of mtDNA's from $\mathrm{N}$ cytoplasms with the variants obtained by in vitro culture and with $\mathrm{T}$ cytoplasm would certainly help us to understand the genetic supports of cytoplasmic Texas male sterility.

The role of nuclear background on the expression and the possibility of modification and amplification of mtDNA during sporogenesis and gametogenesis should be analysed.

Reçu le 12 mars 1985. Accepté le 11 septembre 1985.

\section{ACKNOWLEDGEMENTS}

We thank Dr. John KovGH for help with English translation. 


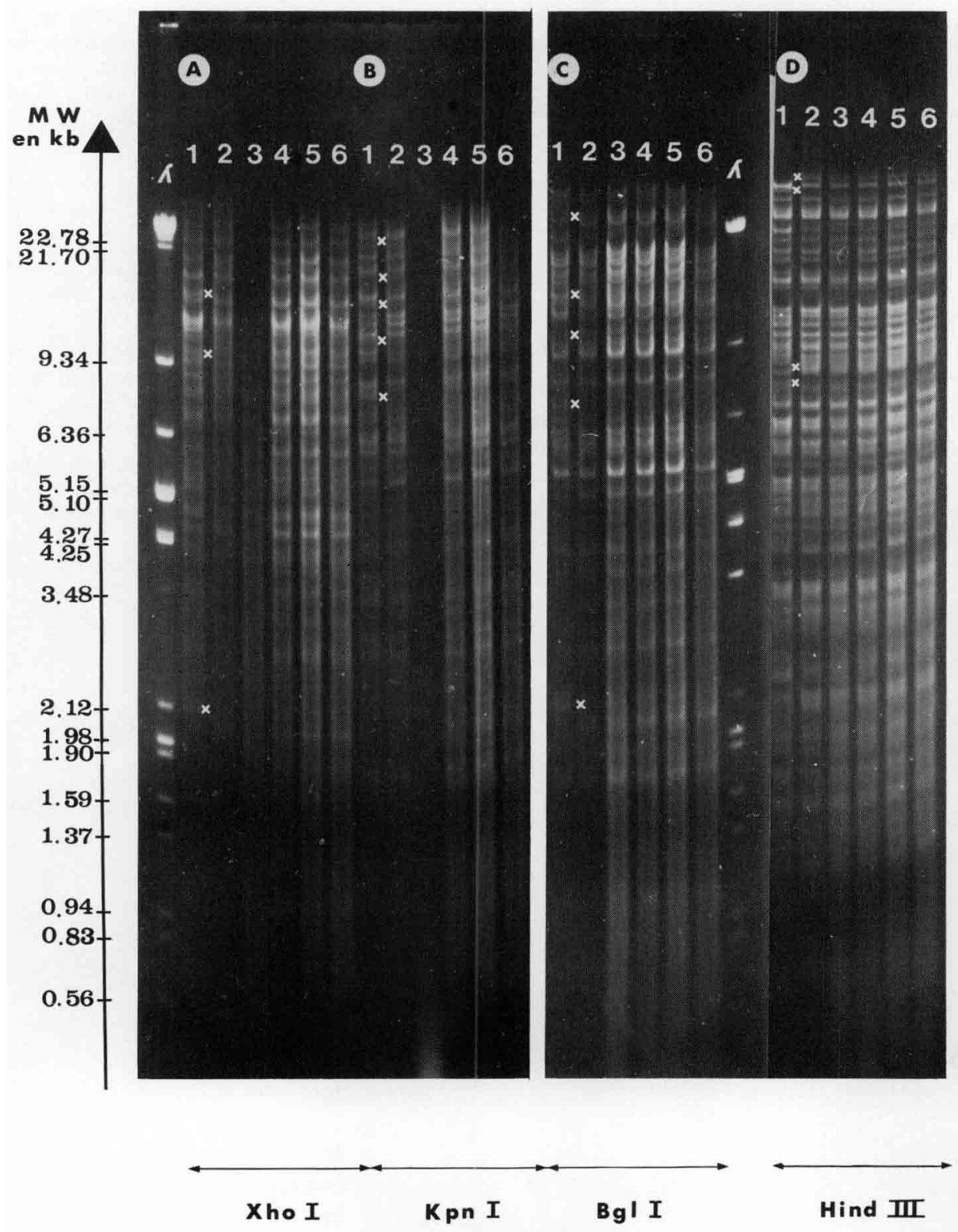

Figure $4 \mathrm{~A}, \mathrm{~B}, \mathrm{C}, \mathrm{D}$

Agarose gel electrophoretic patterns of mIDNA of maize digested by Xho I (A), Kpn I (B), Bg1 I (C), Hind III (D). Lane 1: F71. Lanes $2,3,4,5:$ the mutant families $1754,511,473,135$. Lane 6 : F7 N.

Molecular weight markers are digests of $\lambda D N A$ digested by Eco RI and Hind III (Boehringer, marker III).

$\mathrm{x}:$ differences observed between $F 71$ and $F 7 \mathrm{~N}, 1754,511,473$ and 135 .
Diagrammes électrophorétiques sur gel d'agarose de mtDNA de maiss digéré par Xho I (A), Kpn I (B), Bg1 I (C), Hind III (D). Puits 1 : F7I. Puits 2, 3, 4, 5 : les familles de mutants 1754, 511, 473, 135. Puits $6: F 7 N$.

Les marqueurs de masses moléculaires sont des fragments de DNA $d u$ phase $\lambda$ digéré par Eco RI et Hind III (Boehringer, marker III). $\mathrm{x}$ : différences observées entre F7I et F7 N, 1754, 511, 473 et 135.

\section{RÉFÉRENCES BIBLIOGRAPHIQUES}

Bervillé A., Paillard M., 1982. Comment améliorer chez le maïs la résistance à Helminthosporium maydis race $\mathrm{T}$ et Phyllosticta maydis, 125-136. In : La sélection des plantes pour la résistance aux maladies, Les Colloques de l'I.N.R.A., $\mathrm{n}^{\circ} 11,232 \mathrm{p}$.

Brettell R. I. S., Thomas E., Ingram D. S., 1980. Reversion of Texas male sterile cytoplasm maize in in vitro culture to give fertile T-toxin resistant plants. Theor. Appl. Genet., 58, 55-58.

Cassini R., Cornu A., Bervillé A., Vuillaume E., Panouillé A., 1977. Hérédité et caractéristiques des sources de résistance à $\mathrm{Hel}$ minthosporium maydis race $\mathrm{T}$, obtenues par mutagenèse chez des mais à cytoplasme mâle-stérile Texas. Ann. Amélior. Plantes, 27, 753-766.
Cornu A., Cassini R., Bervillé A., Vuillaume E., 1977. Recherche par mutagenèse d'une résistance à Helminthosporium maydis race $\mathrm{T}$, chez des maìs à cytoplasme Texas, 479-488. In: Induced mutations against plant diseases, Vienne, Int. At. Energ. Agency.

Cornu A., Vuillaume E., Bodergat R., 1981. Intérêt des variants cytoplasmiques en amélioration des plantes. Application à la recherche de maïs résistants aux toxines spécifiques de la stérilité mâle cytoplasmique Texas, 267-275. In : «Induced mutations. A tool in plant breeding ", Vienne, Int. At. Energy. Agency.

Gengenbach B. G., Green C. E., 1975. Selection of T cytoplasm maize callus cultures resistant to Helminthosporium maydis race $\mathrm{T}$ pathotoxin. Crop Sci., 15, 645-649. 
Gengenbach B. G., Connelly J. A., Pring D. R., Conde M. F., 1981. Mitochondrial DNA variations in maize plants regenerated during tissue culture selection. Theor. Appl. Genet., 59, 161-167.

Kemble R. J., Bedbrook J. R., 1980. Low molecular weight circular and linear DNA in mitochondria from normal and male sterile Zea mays cytoplasms. Nature, 284, 565-566.

Kemble R. J., Flavell R. B., Brettell R. I. S., 1982. Mitochondrial DNA analysis of fertile and sterile plants derived from tissue culture with the Texas male sterile cytoplasm. Theor. Appl. Genet., 62, 213-217.

Kemble R. J., Gunn R. E., Flavell R. B., 1980. Classification of normal and male sterile cytoplasms in maize. 2 : Electrophoretic analysis of DNA species in mitochondria. Genetics, 95, 451-458.

Kemble R. J., Gunn R. E., Flavell R. B., 1983. Mitochondrial DNA variation in races of maize indigenous to Mexico. Theor. Appl. Genet., 65, 129-144.

Levings C. S., Pring D. R., 1977. Diversity of mitochondrial genomes among normal cytoplasm of maize. J. Hered., 68, 350-354.
Levings C. S. III, Shah D. M., Hu W. W. L., Pring D. R., Timothy D. H., 1979. Molecular heterogeneity among mitochondrial DNAs from different maize cytoplasms, 63-74. In : Extrachromosomal DNA (ICN-UCLA Symposia). New York. Acad. Press.

Newton K. J., 1983. Molecular correlates of cytoplasmic types. Maize Genet. Coop. Newsl., 57, 138-139.

Pring D. R., Smith A. G., 1985. Distribution of minilinear and minicircular mtDNA sequences within Zea. Maize Genet. Coop. Newsl., 59, 49-50.

Vedel F., Lebacq P., Quetier F., 1980. Cytoplasmic DNA variation and relationships in cereal genomes. Theor. Appl. Genet., 58, 219224

Vuillaume E., Vedel F., Boutry M., 1984. Analysis of native mitochondrial DNA in male fertile maize mutants resistant to Helmin thosporium maydis race $\mathrm{T}$ obtained by mutagenic treatments of seeds with Texas cytoplasm. Agronomie, 4 (3), 291-294.

Wise D. R., Pring D. R., Gengenbach B. G., 1985. Mitochondrial DNA rearrangements associated with reversion of $\mathrm{T}$ cytoplasm to male fertility and disease resistance. Maize Genet. Coop. Newsl., $59,50$. 